\title{
Kaaps: Time for the language of the Cape Flats to become part of formal schooling
}

\author{
Michael le Cordeur \\ Stellenbosch University
}

Correspondence to: mlecorde@sun.ac.za

\begin{abstract}
Throughout the centuries, language has always been a prerequisite for tuition and learning. This contribution is based on the universal theme of language as bearer of cultural identity and the role it plays in South African education, specifically regarding literacy. The focus falls on especially one variant of Afrikaans, known as Kaaps, and the role that it plays regarding the individual and group identity of the group of people who were classified as Coloureds during apartheid ${ }^{1}$ and marginalized by poverty, place of residence and race. The research question is whether Kaaps can make a contribution to the successful delivery of the school curriculum in those schools which are mainly attended by the so-called 'Coloureds' on the Cape Flats. The methodology chiefly entails a literature review. From a socio-historical perspective the article reflects on the history of Kaaps since the early $1600 \mathrm{~s}$, and what role it plays in the development of Afrikaans. The literature study supplies the theoretical framework for reflection on Kaaps. The focus is on the influence of Kaaps on its speakers' perception of their identity; the conflict of Kaaps with Standard Afrikaans; the current status of Kaaps in the Coloured population; the restandardization of Afrikaans, and to what extent, if any, Kaap comes into its own in South African schools. The study comes to the conclusion that learners who grew up with Kaaps, are disadvantaged at school and that the language should be utilized more inclusively.
\end{abstract}

1 The classification of social groups according to race is problematic (Essack and Quayle 2007:73). The term "Coloured" refers to people who were identified as Coloured under apartheid legislation. The terms "white", and "black" are used, not because the author approves terms which labels people on racial grounds, but because they, unlike the word "Coloured" do not occur in apartheid legislation and are thus acceptable to illustrate this point of diversity. 


\section{INTRODUCTION ${ }^{2}$}

In South Africa, language has always been an emotional and often political issue (Le Cordeur, 2011). Since South Africa became a democracy, Afrikaans has lost its status as one of two official languages and today Afrikaans and English share this privilege with nine indigenous African languages. Now that Afrikaans no longer enjoys advancement by the government, the Afrikaans-speaking community is obviously concerned about the future of their language (Pienaar, 2014). This often leads to emotional debates. Most of these are concerned with the conservation of Afrikaans in its standard form within a specific sociocultural context. Language thus plays an important role to indicate who and what we are (Le Cordeur, 2011). Joseph (2004:39) in Dyers (2008:51-2) puts it as follows: '... we read the identity of people with whom we come into contact based on very subtle features of behaviour, among which those of language are particularly central.'

\section{RESEARCH DESIGN}

This study starts with a literature review on a number of burning issues regarding Cape Afrikaans (Kaaps), namely: the history of the speakers of Kaaps (the Coloured people); the group areas act; the 1976 riots in Soweto; the stigma attached to Afrikaans as the language of oppression; the role of Coloured people in the development of Afrikaans; the origins of Kaaps; the stereotyping of Kaaps and the status that this language variant enjoys among Coloured people (especially among the youth). The data from the literature review is used as basis for the argument that Kaaps should be used as language of tuition in school to support the curriculum and as pedagogy to improve the academic achievements of the learners who use Kaaps as home language. The article closes with a look into the future regarding the position of Kaaps within Afrikaans as multifaceted language and the relationship between Kaaps and Standard Afrikaans in particular.

\section{LITERATURE STUDY}

\section{The proud history of Black and Coloured South Africans}

South African history either ignores the heroic contribution of Black and Coloured people in the past, or represents it in a negative way (Rabe, 2011:54). Thus school history books represent the Anglo-Boer War as a battle between Boer and Brit in which the Afrikaner repeatedly emerges as hero, while the contribution of Black and Coloured South Africans is ignored (Sonn, 2014). The issues which caused the war affected Black and Coloured people, and nearly one hundred thousand Black and Coloured people were directly involved in the war, while between ten and thirty thousand White people participated in the war as armed soldiers. The war produced many Coloured heroes (including one Sgt-Major Taylor) about whom nothing appears in history books (Carstens and Raidt, 2015). The Morning Post in Mafikeng reported as follows on the Siege of Mafikeng: 'The Coloured ...

2 This contribution was published in adapted format in Tydskrif vir Geesteswetenskappe, 55 (4), December 2015, under the title 'The issue of Kaaps; Afrikaanse tuition at school requires a more inclusive approach'. 
boys ... are a most gallant race of men and ... very brave ...' (Sonn, 2014).

\section{Separate neighbourhoods, separate languages}

South African history shows that political decisions were taken and executed since its earliest days to force White, Coloured and Black people to live separately from one another (Carstens and Raidt, 2015). A number of examples can be found of this practice: the slave lodge in Cape Town which housed slaves until 1838; the separate areas occupied by White and Black people in the Eastern Border area, and the establishment of the location system by Shepstone in the 1850s in Natal (cf. Giliomee and Mbenga, 2007:148). In the 1950s the Group Areas Act was instituted by the apartheid government. It led to people all over South Africa being forced out of their traditional neighbourhoods: in Cape Town out of District Six to Mitchells Plain and other areas on the Cape Flats, and in Johannesburg, Black people were forced to live mostly in Soweto (cf. Carstens and Raidt, 2015). There are many other examples. In 1932, Coloured people were removed from the voters' roll. They would henceforth be represented in parliament by White people (cf. Du Pisani, 2012:353). The race label of being Coloured left deep wounds and caused much bitterness, as becomes clear in the following poem:

Laat dit dan wees, o Heer, dat ek 'n duisend jaar gelee teen God en mens gesondig het ...

dan weet ek tog, dis u besluit, die vloekstraf van 'n donker huid. (Uit: "Bede", S.V. Petersen. 1944)

[Let it be, o Lord, that I, a thousand years ago, did commit some sin against God and man... Then I would know thus that it was your decision, this curse of a darker skin.] (From: Prayer, S.V. Petersen. 1944)

Since different groupings within the Afrikaans community had lived apart for so long, it caused them to grow apart linguistically. Kaaps speakers and speakers of Standard Afrikaans would eventually become intertwined in an "us and them" relationship.

\section{Kaaps has a long history}

The earliest Kaaps was recorded even before Jan van Riebeeck landed at the Cape in 1652. The earliest periods of the history of Afrikaans began after the visits to the Cape by Van Linschoten in 1592, and De Houtman and Lodewycks in 1595. The VOC (Dutch East India Company) was a trading company with too few workers and too much work; as a result, they decided to import slaves. The first group of slaves came from Angola and Mozambique in 1658 and in the process brought Portuguese to the Cape. Slaves were also imported from the East, which brought Malay to the Cape (Van Rensburg, 2012:26). Many Vryburger farmers had married Khoi-Khoi women or former slaves who already spoke Afrikaans by 1600. Children grew up with their mothers' version of Afrikaans. This Afrikaans is known as Kaaps today (Van Rensburg, 2012:36) and it is the home language of more than 1,5 million people on the Cape Flats (Le Roux and Pissoa, 2011). Although the speakers of Kaaps were mostly Coloured, there were also many White Kaaps speakers (cf. Du Preez 2011). That Kaaps was also the facilitator of its speakers' history is clear in the first verse of Patrick Petersen's poem:

My Xhosa susters en broers, julle moet weet: 
gister en vandag het ons 'n lang pad gekom

ons is nie halfnaaitjies nie

ons is Kaaps ...

[My Xhosa sisters and brothers, you must know:

Yesterday and today we came a long way

We are not half-breeds

We are Kaaps...]

(From: Ons kom van ver af, 1195:79)

\section{Kaaps, language of the Cape Muslims}

One of the first Afrikaans manuscripts was the Muslims' Holy Qu'ran. Many slaves from the East belonged to the Islamic religion and learned to write out verses and religious practices from the Qu'ran (cf. Le Cordeur, 2011a). The Cape Muslim community launched the first school where tuition was in Afrikaans in 1793, namely the Madrassa (Muslim school) in Dorp Street, Cape Town (Davids, 2011:68). The oldest translated Afrikaans text is the Bayân al-Dîn (exposition of faith) which was written in Arabic script by Abu Bakr (Van Rensburg, 1997:13). Davids describes the important role that Muslims ${ }^{3}$ played in the establishment of Afrikaans as follows:

Today [we] know that by the final emancipation of slavery in 1838, not only was Cape Afrikaans the dominant language spoken by the slaves and Free Blacks in Cape Town, but it was written in the Arabic script (Davids, 2011:75).
The Muslims also played a great role in preserving Dutch songs which refer back to the days of slavery (I.D. du Plessis, 1935). In a time when most Afrikaners in Cape Town were anglicizing, they founded the Malay choirs ${ }^{4}$ (Davids, 1994:40). Despite the Dutch origin and lyrics of Cape Muslim music, this cultural contribution was never acknowledged and little of it was recorded. The best known song is probably Rosa, a love song sung at festivals and weddings:

\section{Rosa}

Laas toe ek een meisjie $\left[\operatorname{mes} \int \mathrm{I}\right]^{5}$ het bemin/

En hare naam was Rosa dear

Sy was maar nimlik sestien djare [dfarə] oud (sestien djare [dfarə] oud)

Sy was een meisje [meI I $]$ van haar woord

En sy sê sy sal my nooit verlaat

Sy sê en sy vollig my waar ek gaan

Rosa Rosa dit was haar naam

En sy vollig my waar ek gaan

Dit was drie maande daarna (drie maande daarna)

Ontmoet ek vir Rosa op een straat Spakket ek met Rosa ene word (Rosa ene word)

Dit was die woord van trou akkoord

En sy sê sy sal my nooit verlaat

Sy sê sy vollig my waar ek gaan

Rosa een my Rosa dear Rosa vollig my

djou $\left[\mathrm{d} \int œ u\right]$ swaer

[I once loved a girl named Rosa and she followed me wherever I went, It was three months thereafter I met her on a

3 The term 'Muslim' is used as alternative for 'Moesliem' because it the most common colloquial form.

4 The concept "Malay" is a highly controversial term much criticised by authors such as Achmat Davids, in his study The Afrikaans of the Cape Muslims. The word is only used here because it is the name given to the choirs and is still used today.

5 I transcribe only the words which are pronounced differently from Standard Afrikaans. 
street and spoke a word with her. It was the word of betrothal and she said she would never leave me. She said she would follow me wherever I went, My dear Rosa follows me, your man]

(Desai, 2004)

\section{Stigmatization; language of the oppressor and the Soweto riots}

It was Langenhoven (Hugo, 2009:65) who labelled Afrikaans as a white man's language with his remark in the early $20^{\text {th }}$ century that Afrikaans was the greatest single achievement which had come from overseas with the white man. This remark would eventually lead to Afrikaans being branded the language of the oppressor, especially because Afrikaans was promoted on a racial basis. While Afrikaans was favoured by the apartheid government and the promotion of the standard variety of Afrikaans took precedence, the colloquial variants of Afrikaans, including Kaaps, did not receive the necessary acknowledgement (cf. Odendaal, 2011).

The push for change in the Black, Coloured and Indian population grew increasingly stronger and it was only a matter of time before the people rose up against the apartheid state. The Soweto riots on 16 June 1976 spilled over to the rest of the country and is still considered by some to be a protest against a language policy which forced Afrikaans on black people. The language of the struggle was mainly English and 'the hunt was on and Afrikaans was the target' (Van Rensburg, 2012:133). Nevertheless, Coloured voices were incorporated into the great black consciousness protest movement and the uprising in the vast Cape Flats also increased.

Many Coloured people were shot during the 1970s and 1980s, or were arrested and tortured (cf. Carstens and Raidt, 2014; Le Cordeur et al., 2012). Thus, for example, the young activist Ashley $\mathrm{Kriel}^{6}$ was shot by the Security Police in July 1987 for his role in the anti-apartheid protests. At this time, for Coloured people, Dr Allan Boesak became a symbol of their participation in the struggle for freedom. His legendary undertaking at the World Council of Churches that he would fight apartheid was expressed in Afrikaans. And Basil Kivedo, the former MK soldier and currently member of Parliament, admitted that he had fought his 'Umkhonto battle in Afrikaans'. Titus (2012) confirmed this fact: '(W)hen we as students in the Western Cape began to give effect to 16 June 1976, we fought the battle in Afrikaans.' Even at school it was Afrikaans-speaking youths who were at the forefront of the struggle (Le Cordeur et al., 2012:70). Coloured people thus played a big role in the struggle, and they did so largely in Afrikaans.

\section{Kaaps versus Standard Afrikaans}

From the preceding section it is logical that the 'Coloured voice' could not be part of the vocabulary of Afrikaans literature, mainly because Kaaps as spoken language variant of many Coloured people was considered a deviation from Standard Afrikaans. The standardization of Afrikaans was considered a strategic process (Deumert, 2004:9) which was

6 Compare among others Wikipedia 2014 (101) on Ashley Kriel. Morton (2014) discusses the role of young people, like Kriel, in uprisings where there was injustice. 
closely related to the apartheid ideology and Afrikaner nationalism (Roberge, 1992). Odendaal (in Van Heerden, 2013) agrees:

(i)t is common knowledge that, historically, Afrikaans was racially informed and ideologically controlled by the oppressor. Whilst standard Afrikaans was appropriated by the oppressor; other varieties of Afrikaans were not recognized.

Odendaal (2011) declares in this regard: "Standardization is not merely a technical exercise - it is politically motivated." This standard, she says, does not represent the total language community of Afrikaans. Odendaal (2013) further indicates that a number of attempts have been made since the 1980s to acknowledge the spoken language variants of Afrikaans. Nevertheless, standardization continued to deny the creole nature of Afrikaans, while the language was purified of Khoi, Malay and slave influences. The consequence of this purification process was that Standard Afrikaans was seen as 'civilized' Afrikaans, while colloquial variants (like Kaaps) were considered to be uncivilized.

The protest poems of Coloured poets and writers who survived the struggle years was their way of rebelling against their exclusion from mainstream Afrikaans. Van Rensburg (2012:130) echoes this sentiment and mentions that Adam Small and other authors indeed used Kaaps in their literary works as a protest action against Standard Afrikaans, and bases his view on the fact the Coloured people were by far the majority in the Western Cape. 'Why is it so important to preserve the standard variety whilst "Kaaps" is the mother tongue of over two million people in the Western Cape?' he asks.

The generally acknowledged meaning of standard language is that it is the language form associated with contextual uses which enjoy a certain prestige value, such as academic language, public speaking language, and tuition material (Carstens, 2011:285, Van Rensburg, 1997:43). Kotzé (2009) argues that the selection of the 'standard grammar' of Afrikaans was the collective result of a mutual consultation process by many language users and academics. Thus in the most recent edition of the Afrikaanse Woordelys en Spelreëls (Afrikaanse Vocabulary List and Spelling Rules or AWS) about 80 new Muslim words have been included. This is an important step because, while spoken language varieties were previously considered to be inferior forms, today it is accepted that the varieties of a language are equivalent components of the language (Ponelis, 1994:107). Standard Afrikaans is thus one of the varieties of Afrikaans, beside other varieties, which is used for higher functions (Carstens, 2011:82; Van Rensburg, 1997:31). Ponelis's (1994:106) view that Standard Afrikaans had enjoyed a golden century, but that this era had reached a turning point which held important consequences for the language, is thus very relevant in terms of the current debate.

Hendricks (2013) consequently argues that a re-standardization of Afrikaans is unavoidable. He adds:

One would hope that Standard Afrikaans will in future be increasingly expanded and enriched by taking into account a significant number of varieties, especially Kaaps.

Odendaal (2011) agrees. According to her, the re-standardization of Afrikaans should focus on normative and ideological language planning which takes into account the needs of the total speaking community. Thus, the re-standardization of Afrikaans 
will lead to the empowerment of its speakers - psychologically, ideologically, economically and academically. If this happens, the words with which Adam Small addressed his critics 50 years ago, become relevant once more:

Kaaps is a language, a language in the sense that it bears the full fate and destiny of the people who speak it; their whole fate, their whole life 'with everything that is in it'; a language in the sense that the people who speak it, give their first cries in this language, all transactions in their lives are concluded in this language, and their death rattle is rattled in this language. Kaaps is not a joke or a comedy.

(Adam Small, Kitaar my kruis, Foreword).

The last point in Small's statement above ('Kaaps is not a joke or a comedy') deserves to be further investigated, and is thus the theme of the next section.

\section{Kaaps is not a joke}

Kaaps is often denigrated as a 'Gammat' language riddled with Gatiepie jokes (Van Wyk, 1997). Gammat is a male proper noun derived from Mohammad (pronounced in Arabic as 'Moegammad' and thus by implication constitutes a negative reference to the influence of Muslim Afrikaans). The stigma that Kaaps is a 'joke' language is nothing new (cf. Trantraal in Marais, 2013). Already with Small's first works there was criticism by Coloured intellectuals that suggested that Small by his use of Kaaps had stereotyped Coloured people and represented them in disparaging ways (Gerwel 1985). This criticism according to Gerwel (1985:16) was unfounded, because Kaaps - as in Small's drama Kanna hy kô hystoe (1965) - was an effective language medium of protest against political injustice. Small responded to his critics as follows in a poem:

Ek sê ek praat met djou in Kaaps

Here some van my critics het nog never in allie djare my taal hierso geperform nie ek sê ma net weer net soes lank gelede die's g'n Gamat-taal nie. 'n straight en diep taal vannie mense waar hulle in gebore word en eerste kwyl

en dan allie transactions van hulle lewe in beklink hulle bietjie maybe baie liefde soek, en haat

en dan, daa' byrie final beacon vannie dood, in sterwe en, dja of course djy moet dit sing

[I speak to you in Kaaps, God some of my critics have never performed my language here in all the years; I just say again, as I did a long time ago, this is no Gamat language. A straight and deep language of the people in which they are born and in which they first drool and then conclude all transactions of their life, they maybe look for a little, maybe lots of love, and hate, and then, at the final beacon of death, die, and yes, of course you must sing it.] (From: Kitaar my kruis).

Hendricks says further: 'Small and Snyders have shown how Kaaps can be bearer of the greatest literature.' Another poet, Daniël Hugo (2013), supports this view and the writer Jeanette Ferreira (in Hugo, 2013) is of the opinion that Small is the one writer who can give substance to the power with which Kaaps can express people's pain. 
Willemse (2012, in Van der Merwe, 2013, and also in this special edition) argues that 'Kaaps is probably the most stigmatized Afrikaans dialect'. According to Willemse (2012), Kaaps is linked to the so-called humour of the Coloured people, as in the many Gatiepie jokes - similar to the Blackface figure of the American pop culture and is represented as socially inferior: 'In the dominant imaging, speakers of Kaaps are often considered to be naïve, shufflingly subservient, half-skilled and with an inability to understand or appreciate complexity.' Repeated pleas have been asking for the stigmatization of Kaaps to be halted because it offends its speakers (cf. Odendaal, 2011, Le Cordeur, 2013b). Willemse (in Van der Merwe, 2013) advocates that the media should play a role in making people aware of this stigmatization. Despite the pleas, the stereotyping of Kaaps and its speakers still occurs in the media. But not all speakers of Cape Afrikaans are passionate about their dialect and identity. As a result, Peter Snyders writes self-deprecatingly and satirically about their lack of language pride and cultural self-confidence:

Of hoe? - Peter Snyders ${ }^{7}$

Moetie rai gammattaal

gebrykie

dit issie mooi ni:

dit diegreid die coloured mense of hoe?

Wat traai djy

om 'n coloured culture te create?

of dink djy is snaaks

om soe te skryf

of hoe?

Traai om ôs lieweste op te lig; ôs praat mossie soe nie ...? of hoe?

7 The poems in this article were quoted verbatim.
[Don't use that "Gammat"

language, it isn't nice; it degrades

the coloured people - not so?

Why do you try to create a coloured culture? Or do you think it is comical to write like that? Rather try to uplift us; we don't talk like that...? Do we?] (From: Versagtende omstandighede, 1995).

Another concerning aspect is the idea that Kaaps is a so-called 'gangster' language. 'No', says Hendricks (2013), 'I cannot associate with equating Kaaps with gang language. Cape gang language is but one register distinguishable in Kaaps.' After Joan Hambidge (2013) referred to his 'gangster language' in a review of Nathan Trantraal's collection Chokers en Survivors, Trantraal reacted aggressively: ' ... if I speak Gangster, she speaks Boer. Joan's comment about gangster language was shocking to me because she is supposed to be a highly regarded academic.' Trantraal (2013) added that he was the one Afrikaans writer who was in a good position to say anything about Kaaps and its literary works: 'You see, I speak the language and live in it.' The last word here goes to Willemse (in Titus, 2012): 'It is about the dignity of people, not about the acknowledgement of a language form.'

\section{Kaaps as bearer of identity}

Alexander (1994:24) pointed out long ago that in Afrikaans a search for identity was often used as a political pawn. According to Pienaar (2014), for many white Afrikaans speakers, Afrikaans is part of their identity. It defines who and what they are. He further states: 
... (1)anguage is woven much deeper into our being and identity than most of us realize. We do not only learn language from one another, we also learn certain patterns of thought along with it. The language we speak is thus more than just an instrument of sound and communication. Our language is part of how we experience and see ourselves, how we express ourselves and understand the world (Pienaar, 2014).

For Coloured speakers of Afrikaans, it is no different (Le Cordeur, 2007:5), but they are less outspoken about it, and according to Gerwel (1985) they have made peace with the language they speak. Coloured people are not militantly involved with the language conflict, because their existence is not threatened by the scaling down of Afrikaans. Carstens and Raidt (2015) point out that Coloured culture had for years been associated with the cheerful Minstrel Carnival in the Cape around New Year. This is not, however, all that Coloured culture consists of, and there is still much to be explored and to be learnt from one another. Le Cordeur (2014e) refers to the ATKV's annual Riel Dance competition at the Afrikaans Language Monument in Paarl:

(it's) a festival where more than 4000 supporters from the total Afrikaans community celebrate the true freedom of Afrikaans; Afrikaans with all its variety, colour and spice. Here the words of NP van Wyk Louw, engraved on the rock of the language monument, acquire new meaning when he says:
Afrikaans is the language linking Western Europe and Africa: it forms a bridge between the bright West and magical Africa. Perhaps this is what lies ahead for Afrikaans to discover.

Furthermore, Le Cordeur and Le Roux (2013) in the book Die Wellingtonse Klopse: 100 jaar se onvertelde stories emphasize that the Minstrel Carnival is an opportunity to recall the hard fought freedom of the erstwhile slaves. The minstrel songs are about more than just good cheer. They express the full fate and destiny of the people (Small, 1962). One of the most popular items on the Carnival Programme is the moppie ${ }^{8}$, for which the original Afrikaans lyrics are written by die groups themselves. The following song delivers social commentary on the riots which were matched by a workers' strike. It expresses people's pain due to the empty promises of better salaries and highlights strikers who toi-toi in the streets without knowing if there will be a solution - and yet remain loyal to South Africa.

\section{Viva Suid-Afrika!}

Ons hoor, ons hoor, ons hoor [We hear, we hear, we hear] Hulle ammal doen die toi toi toi (x2) [They all do the toi-toi] Daar's onrus in Nyanga, Khayalitsha en Langa [There's unrest in Nyanga, Khayalitsha and Langa]

Orals in Suid-Afrika [Everywhere in South Africa]

hoor ons die mense praat. [We hear how our people speak] (seblief tog, seblief tog) [(please, please)]

8 Moppies, derived from the Dutch word mopje (little joke), are songs with satirical commentary about anything in society but especially about socio-political aspects. 
Die Kaap is ani brant [The Cape is burning]

Kyk dis oppi TV [See it's on the TV]

En inni squatter kamp. [And in the squatter camp]

Eers het ossi geworry nie [At first we didn't worry]

toe was alles tax free [Then

everything was tax free]

Maar toe kom die GST [But then

came the GST]

En nou issit VAT [And now it is the VAT]

VAT op koffi, VAT op tie [VAT on coffee, VAT on tea]

VAT op vleis en rys [VAT on meat and rice]

Maar niks op 'n stoppie nie. [But nothing on a pipeful]

Die manne het in die van gebly

[The guys stayed in the van]

Vir die drie dae stayaway [For the

three day stayaway]

Cosatu het gesê dat hulle Vrydag vi' os sal pay [Cosatu said they would pay us on Friday]

Die een djol voor met ' $n$ vlag inni hant [One prances ahead with a flag in hand]

Die aner djol ammal agteran [The others all follow him]

Dis deerie strate tot oppi perara [Through the streets to the Parade]

Toi toi ammal saam [They all toi-toi together]

Mense mense, [People, People] sing sing sing ons ammal [We all $\operatorname{sing}]$

sing ons ammal saam (x2) [We all sing together]

Viva Suid-Afrika! [Viva South Africa!]
(From: Le Cordeur and Le Roux, 2013)

In one of his earliest poems, S.V. Petersen expresses the feeling of the Coloured man towards his Afrikaner employer:

Weet dit

[Know this]

vir my bly jy 'n vreemdeling,

niks meer; [To me you

remain a stranger, no more; ]

jou vader was 'n slaaf,

[Your father was a slave,]

en myne was 'n heer!"

[And mine a lord!]

(From: Verwantskap ${ }^{9}$, 1944).

The Coloured voice looks at the blood relationship between the two men. Years later, Van Wyk Louw ${ }^{10}$ strongly argues for his fellow citizens to consider white and Coloured as one nation: 'The Coloured people are our people,' he says, 'they belong with us.'

The findings of a study (Saal and Blignaut, 2011) indicate that the use of Teen Kaaps is experienced positively by teenagers who speak the language. The teenagers surveyed in the study indicated that Kaaps was 'hip' and 'cool', which could be an indication of changing perceptions about Kaaps since 1994. Taking everything into account, it can be stated with certainty that Kaaps enjoys a certain stature in the community and in the arts. This language form succeeds in releasing a certain energy into the working class Afrikaans speakers on the Cape Flats. Le Cordeur (2007:5) argues that the group attaches value to the work of poets, playwrights and singers in which this dialect is engaged. Compare

9 Incorporated in the collection Die enkeling, 1944.

10 In his foreword to Die opkoms van ons derde stand, 1960. 
in this connection Adam Small's Kanna hy kô hystoe which was sold out at the Stellenbosch Woordfees in 2014, the popularity of the drama My naam is Ellen Pakkies locally and abroad, the popularity of rap and hip-hop artists like Brasse vannie Kaap and Hemelbesem, the success of theatre productions like Joe Barber, Marlene le Roux's Plekkie in die son, the production Ghoema (Taliep Petersen and David Kramer), the music of the Jaloersbokkies and the Rockets as well as the poetry of Peter Snyders and Patrick Petersen and of younger poets like Nathan Trantraal and Ronelda Kamfer. In addition, Adam Small's Kitaar my Kruis (1962) was praised by establishment critics for the way in which Kaaps expressed 'the deep inner turmoil of the Coloured people' (Hugo 2013). Kaaps is thus indeed an important indicator of both group and individual identity.

\section{The contribution of Coloured people to the development of Afrikaans}

From the preceding it is clear that the history of Coloured people is closely intertwined with the language. Nevertheless, it appears that the role of Coloured people in the development of Afrikaans has not been acknowledged. In the apartheid era, this group was classified as 'Cape Coloureds'. Most of them have Afrikaans as mother tongue (Le Cordeur 2011a), live chiefly in the Western Cape around Cape Town and possess the skill to change language codes: 'Some can comfortably codeswitch between "Kaaps"...,"pure Afrikaans", and English' (Du Preez, 2011:3). This means that the opinion of nearly three million people for whom Kaaps is a home language, a religious language, a cultural language and an emotional language, are often ignored when Afrikaans is considered.

Seen against this background, the position of Coloured poets and writers who wrote in Afrikaans during the apartheid era was often contentious. The labelling of Afrikaans as 'white man's language' also haunted the poets Adam Small and S.V.Petersen, because in the older Afrikaans critique there was open racial categorization. In Dekker's (1966:292) literary history, S.V.Petersen is referred to in a derogatory way as 'the voice of the Coloured which is still unskilled' and is not yet 'real poetry'. By typifying Small as 'black Sestiger' (Dekker, 1966:292), his contribution to the growth of Afrikaans literature is indeed acknowledged, but on the other hand his marginalization in that literature is also implied: a matter of being inside, but also outside.

With the dawn of democracy, however, the playing field changed. Afrikaans had to relinquish its powerful position and although it is still an official language, it now shares this position with ten other languages. What will become of the 'Coloured voice' in this new dispensation will depend, according to Pakendorf (2011), on 'the extent to which the guardians of norms are prepared to abandon the old holy cows'. Because even if the open use of 'sensitive' colour labels are currently banned, the race card has never really disappeared. The fact that Adam Small's oeuvre was ignored for so many years, regarding the awarding of South Africa's top literary prize, is the clearest sign of this. This matter was eventually corrected in 2012 when the Hertzog Prize was awarded to Small. The bitterness of Floris Brown, who according to Le Cordeur (2011c) had published 24 collections himself, 
because he was ignored by publishers, becomes apparent in the following verse:

Mense hou nie daarvan om

woorde te lees wat kwel

aan hul vel, dus, is ek tot vandag geen uitgewer se pêl.

(People don't like to read words which vex their skin, thus, I am to this day no publisher's pal.)

(From: Kaleidoskoop 2011 ${ }^{11}$ )

The adjustments will thus have to be comprehensive and the school curriculum will have to be subject to this reflection. Where do the impressive number of Coloured writers and poets fit in - one thinks of Adam Small, Peter Snyders, Patrick Petersen, EKM Dido, Nathan Trantraal, Ronelda Kamfer, Dianne Ferrus and Clinton V. du Plessis - in a changing body of literature? And will publishers eventually publish the words of poets like Floris Brown? And according to which benchmarks, asks Pakendorf (2011), would their poetry now be acceptable?

\section{Kaaps in the school curriculum}

For political reasons, Coloured, Black and White learners attended separate schools in the apartheid period (1948-1993) (see 6.2.2). After 1994 the separation of schools started to disappear and today integrated schools are a common phenomenon. However, the aftermath of apartheid education will still be with South Africa for a long time (Carstens and Raidt 2015). One of the consequences of apartheid education is that the level of literacy in the Coloured and black communities is lower than among their white peers. In conjunction with the underdevelopment of Coloured people's formal language skills for many years, a variety like Kaaps was dismissed as substandard. By the end of the twentieth century speakers of Cape Afrikaans started to object strongly to the fact that children who had grown up with Kaaps had to do all their schoolwork in Standard Afrikaans (Esterhuyse, 1986). One of their objections was that the prescribed books portrayed a world that differed from that in which the children had grown up.

Sonn (2014) responded as follows: 'To develop a sense of pride, a sense of self-esteem and a true sense of unity, it is important that the history we teach our children should be corrected.' (See 6.2.1.) Willemse (2011) pointed out that here, as in Jamaica and in a number of American cities, teachers were aware that their learners' non-standardized language varieties were stigmatized economically, culturally and even politically. He argues that teachers feel obliged to teach the standard variety of the language to their learners, to prevent them from being subject to teasing and lower performance expectation. Willemse (2012) agrees with Sonn (2014) and emphasizes the important role of the teacher to create space for empowerment by restoring pride in the language with which the learners are familiar. Due to the teachers' pragmatic attitudes, learners systematically lose their self-confidence speaking their home language, and according to Willemse (2011) the children of the Cape Flats often have deficient self-esteem because they feel uncomfortable in Standard Afrikaans in the education situation. Many Coloured people still have a negative attitude towards Afrikaner nationalism (Du 
Preez, 2011). As a result, many speakers of Kaaps tend to speak English in formal circumstances.

From the preceding it is clear that change is necessary regarding the attitude of the education department towards the use of colloquial varieties like Kaaps. As stated by Hendricks (2012), language tuition at school should serve to destigmatize colloquial varieties. This change must start with the community because rebuilding the community is an integral part of the process of change (Le Cordeur, 2013) and it is very relevant to the current debate about the utilization of Kaaps as medium of tuition. According to the latest Curriculum and Assessment Policy Statements (CAPS ${ }^{12}$ ), the curriculum must inter alia address the following principals: diversity, equality, social justice, language and quality education. It is the task of the community to ensure that these aims are achieved, so that learners, irrespective of their socio-economic background, race, gender, physical and intellectual abilities, will be equipped with the knowledge, skills and values required for fulfilment and meaningful learning (DBE, 2011).

A key aspect in the delivery of a curriculum is how knowledge is received, constructed and transmitted (Le Cordeur, 2014c). In this regard, the curriculum is deeply intertwined with the institutional culture of schools. If schools thus continue to ignore the language varieties, the institutional environment, like the language of tuition, does not promote curriculum development or academic success (Le Cordeur, 2014d). This also applies to the way Kaaps is handled on the Cape Flats where the failure rate is very high. The question must therefore be asked whether the curriculum has sufficiently transformed to make a contribution to the academic success of learners who grew up with Kaaps. It is especially important because experts (cf. Vilakazi 2002; Heugh 2010) agree that the language in which the curriculum is conveyed is at the core of the South African education crisis.

Mehrotra (1998:479) puts it as follows:

$\ldots$, if the medium of instruction in school is a language that is not spoken at home, the problems of learning in an environment characterized by poverty are compounded, and the chances of drop-out increase correspondingly.

Before learners can thus master the subjects, they must first overcome the barrier, i.e. the language of tuition (Heugh 2010). The role of Kaaps is thus of critical importance for the successful delivery of the curriculum because it influences the academic success of more than 2.5 million learners. Against this background, that I ask (cf. Le Cordeur 2013a) that provision be made for Kaaps in the school curriculum. The reason being that children from the Cape Flats underachieve in the national assessment tests, especially reading, because they are tested in Standard Afrikaans. Odendaal endorses this view and reports that research at the University of Stellenbosch (Odendaal, 2012) indicated that the results of learners with Kaaps as home language were below average (lower than $50 \%$ ) if the literacy tests were in Standard Afrikaans. When the test was rewritten in Kaaps, the learners performed better. I therefore propose that learners at school

12 CAPS is the abbreviation for Curriculum and Assessment Policy Statements and the general term used to refer to the new curriculum (2011) in South Africa. 
should be allowed to express themselves in the language they speak.

Paddy Atwell of the Western Cape Education Department (WCED) responded as follows to the proposal by Le Cordeur (2013a):

...it is an interesting proposal by Dr Le Cordeur, but not practical, and the WCED shall continue with the tuition of English, Afrikaans and Xhosa as languages of tuition and learning in the province, in line with the national policy. We do, however, acknowledge the unique contribution that Kaaps makes to linguistic diversity (Die Burger, 2013).

Atwell was thereafter widely criticized in social media by readers with Kaaps as home language. Under the heading Moeti Afrikaaps vi' 'n kleintjie vattie (Don't take Afrikaaps for granted) Genl. Maj. Jeremy Vearey, commander of the Mitchells Plain-police cluster responded in Kaaps on his Facebook-profile:

Vêre slat ekkie Cape Times van gister oep en my oeg val oppe lipstuk van daai engelsman Paddy Attwell vannie WKOD.

Dit gaan blykbaar oo Bra le Cordeur gesnipet rat os skool-laaities oppie Cape flats in Afrikaaps geblackboard moet wies. Nou die engelsman spieg 'n gwarra dat Bra Michael se proposal was interesting but not practical. Kantie wies djy mettie hoegende Engels? Waavandaan kamka djy? Anyways, wat is 'standard' Afrikaans en wie sê wattie 'standard' moet wies?"13

[I opened the Cape Times yesterday and my eye fell on the piece by that Englishman Paddy Atwell of the
WCED. It is apparently about Bro le Cordeur who argued that our school kids on the Cape Flats should have been taught in Afrikaaps. Now the Englishman indicated that Bro Michael's proposal was interesting but not practical. Can it be: you with the pompous English? Where do you come from? Anyway, what is 'standard' Afrikaans and who says what 'standard' is?]

It appears that the pleas of those who argue for the inclusion of Kaaps in the school curriculum did not fall on deaf ears, because Kaaps is increasingly being used in the classroom. The poems of Marius Titus, Peter Snyders, Adam Small, and recently also the poetry of Patrick Petersen, Nathan Trantraal and Ronelda Kamfer, are being studied at school. Novels like Diekie vannie Bo-Kaap by Zulfa Otto-Allies (used in Grade 9) and the inclusion of Kaaps idioms and expressions in a new textbook series ${ }^{14}$, introduces youngsters to cultural issues to which they had little exposure before. And dramas like Adam Small's Krismis van MapJacobs and Kanna hy kô hystoe give young people insight into an indigenous value system.

\section{In closing: looking to the future}

Language is without doubt one of the most important challenges to academic success, despite South Africa's Language Policy which stipulates that language should not stand in the way of learning (National Language Policy, 1996). Afrikaans consists of many varieties; as a result, it was necessary to investigate one of the most well-known varieties of

13 Pretorius, Maahir. 2013. Moeti Afrikaaps vi' 'n kleintjie vattie. Facebook, 10 July.

14 Le Cordeur et al. 2014. Platinum Afrikaans Huistaal, Grade 9, Pearson: Cape Town. 
Afrikaans - Kaaps - especially in terms of how it is experienced in the daily lives of its speakers. From the literature reviewed in this study, and the discussion which emanated from it, it is clear that the child who grew up with Kaaps is disadvantaged at school.

The Department of Basic Education currently faces the huge challenge of ensuring that all learners receive tuition in their home language and to manage it in a more inclusive way than is currently the case. Much water has run under the bridge since S.V. Petersen's poetry first appeared in 1944. Afrikaans has lost its status of privilege, and even the youth who grew up with Kaaps now has a different view of their dialect. This variety should thus be granted the space that is required and, as Scholtz (2013) indicates, nobody in their right mind would today dare to oppose the development of Kaaps. The onus is now on all with an interest in Afrikaans to give direction on how a variety like Kaaps can in future be utilized and come into its own in the domain of education. The words of Madge du Preez (2011) serve as inspiration to each speaker of Kaaps:

Reclaim your identity! Kaaps has definitely not been erased from South Africa's collective consciousness! It is alive and well! It is enjoyed by people on and off the stage, on national TV and in the homes and streets of Cape Town. It is a language that brings about change. It is dynamic and creative. Without a doubt ... a language that has a place in our society.

It would however, to support Scholtz (2013), be a mistake to ignore Standard Afrikaans completely and throw out the baby with the bathwater. But Kaaps is fully Afrikaans and should be utilized as medium of tuition, alongside Standard
Afrikaans.

I conclude with a prayer by Adam Small:

... seën hierie taal oek Here,

Kaaps en Afrikaans wat, soes ek

Djou vertel het,

singend is, bestem virrie

kitaar:

'n taal met curves, het ek

vi' Djou gesê,

soes van 'n sexy engel ...

[... bless this language too, Lord; Kaaps and Afrikaans, which, as I have told you, is singing, destined for the guitar; a language with curves, I have told you, like those of a sexy angel ...]

(From: Kitaar my kruis, 1962).

\section{REFERENCES}

Abrahams, Peter; Beukes, Eugene; Boezak, André; Petersen, Patrick and Isak

Theunissen. 1995. Ons kom van ver af. St. Helena Bay: Prog.

Adhikari, Mohamed (ed.). 2009. Burdened by Race: Coloured Identities in Southern Africa. Cape Town: Juta.

Alexander, Neville. 2010. Die uitdagings vir moedertaalonderrig in 'n veeltalige konteks met 'n spesifieke fokus op Afrikaans. Paper read at the congress of the Afrikaans Language Board, Artscape, Cape Town, 27 August.

Beeld, 2014. Inklusiwiteit sal Afrikaans almal se taal maak. 19 January. p. 9.

Boesak, Allan. 2009. Running with Horses: Reflections of an Accidental Politician. Joho! Publishers.

Carstens, Wannie. A.M. 2011. Norme vir Afrikaans. Enkele riglyne by die gebruik van Afrikaans. Pretoria: Van Schaik Publishers.

Carstens, Wannie. A.M. and Raidt, Edith H. 2015. Die storie van Afrikaans: uit Europa en van Afrika. Pretoria: Protea Boekehuis. 
Davids, Achmat. 2011. The Afrikaans of the Cape Muslims from 1815 to 1915. Willemse, Hein. and Suleman Essop Dangor (eds.). Pretoria: Protea Boekhuis.

Dekker, Gerrit. 1966. Afrikaanse Literatuurgeskiedenis. Cape Town: Nasou.

Desai, Desmond. 2004. Adjusted performance requirements in musico-stylistic conversation strategies for the Cape Malay Nederlandslied. Paper read at the 31st annual congress of the Musicological Society of Southern Africa, Stellenbosch. 26-27 August.

Deumert, Anna. 2004. Language standardization and language change: the dynamics of Cape Dutch. Amsterdam: John Benjamins Publishing.

Die Burger, 2013. Erken Kaaps as taalvariëteit. 7 July, p.8.

Du Pisani, Kobus. 2012. B.J. Vorster en afsonderlike ontwikkeling. Joernaal vir Eietydse Geskiedenis. 34(3): 345-368.

Du Plessis, Isak.D. 1935. Die bydrae van die Kaapse Maleiers tot die Afrikaanse volkslied. Cape Town: Nasionale Pers.

Du Preez, Madge. 2011. Breaking through the language barrier - "kaapse afrikaans": a tool to effect change in society. Afrikaaps: ABRAXAS. 11 June.

DBE (Department of Basic Education). 2011. Curriculum and Assessment Policy Statements (CAPS): Intermediate Phase home language. Pretoria: Government Printer.

Dyers, Charlyn. 2008. Language Shift or Maintenance? Factors Determining the Use of the Afrikaans Language among Some Township Youth in South Africa. Stellenbosch Papers in Linguistics (SPIL), 38:49-72.

Essack, Zaynab. and Quale, Michael. 2007. Students' perceptions of a university access (bridging) programme for social science, commerce and humanities. Perspectives in Education, 25(1):71-84.

Esterhuyze, Jan. 1986. Taalapartheid en Skoolafrikaans. Emmarentia: Taurus.

Gerwel, Gert Jakes. 1985. Van Petersen tot die hede - 'n kritiese bestekopname. In: Smith, J., Van Gensen, Alwyn and Willemse, Hein. (eds.). Swart Afrikaanse skrywers. Report of a symposium held at the University of the Western Cape.
Bellville: University of the Western Cape. pp. 11-21.

Giliomee, Herman. and Bernard Mbenga. (eds.). 2007. Nuwe geskiedenis van SuidAfrika. Cape Town: Tafelberg.

Hambidge, Joan. 2013. Chokers en Survivors: Kaaps en in your face. Review. LitNet. 3 July.

Hendricks, Frank. 2012. Om die miskende te laat ken - "n blik op Adam Small se literêre verrekening van Kaaps. Tydskrif vir Letterkunde. 49(1):95-114. . 2013. Kaaps behoort aan 'n iedere. Rapport. 11 Augustus. p.11.

Heugh, Kathleen. 2008. Language policy and education in Southern Africa. In: May, Stephen. and Nancy H Hornberger. (eds.). 2008. Encyclopedia of Language and Education, Volume 1: Language policy and political issues in Education. Springer Science and Business Media LLC. pp. 355-367.

Hugo, Daniel. (red.). 2009. Halala Afrikaans. Pretoria: Protea Boekhuis.

Kannemeyer, John C. 1983. Geskiedenis van die Afrikaanse literatuur 2. Pretoria, Cape Town and Johannesburg: Academica.

Kivedo, Basil. 2003. Wie is die bruin gemeenskap? LitNet. www.oulitnet.co.za/ seminaar/kknkkivedo.asp. [Retrieved: 16/04/2014].

Kotzé, Etnst. 2009. Hoe standaard kan 'n taal wees? Perspektiewe op die teenstrydighede van Afrikaans. Paper read during the Roots conference, University of the Western Cape, Bellville. 22-23 September 2009.

Le Cordeur, Michael L.A. 2011a. The varieties of Afrikaans as carriers of identity: A socio-cultural perspective. Tydskrif vir Geesteswetenskappe, 51(4): December. . 2011 b. Die rol van die bruinmense in die ontwikkeling van Afrikaans in Suid-Afrika. Paper read at the Afrikaans Festival, 17-19 June, Amsterdam. . 2011c. Hoe sal ek 'n digter word? Oorsig oor die digkuns van Floris Brown, township-digter van Worcester. Die Burger. 1 Oktober, p. 12. . 2012. Kaaps in Fokus: Verrekening van 
variëteite in die Onderwys. Paper read at the Symposium presented by the departments Linguistics and AfrikaansNederlands, University of the Western Cape, Bellville. 19-20 July 2012.

. 2013a. Kaaps: a variety of Afrikaans that underpins the individual and collective identities of the people on the Cape Flats. LSSA/SAALA/SAALT Conference. 1-4 July. Stellenbosch University. . 2013b. Grap oor Moesliem in swak smaak. Rapport. 6 Julie. p. 9. . 2013c. Al wat ons kan doen, is dankie te sê vir Madiba. Rapport Weekliks. 8 December. p. 12. . 2014a. Wie se Afrikaans? Implikasies van die variëteite van Afrikaans op die Onderwyspraktyk. Paper read at the Symposium of the Afrikaans Language Board at the Woordfees. Stellenbosch University. 15 March. . 2014b. The role of language and identity in supporting socio-economic development: the case of Kaaps and the Kaapse Klopse. Paper at the Twenty-First International Conference on Learning, Touro University, New York City, USA. 14-17 July.

. 2014c. The Language debate at four former Afrikaans universities: Quo vadis for Afrikaans and Stellenbosch University? South African Review of Education. April. . 2014d. Is Afrikaans almal se taal? Symposium of the SA Akademie vir Wetenskap en Kuns (SA Academy for Science and the Arts): 17 January. University of Pretoria. . 2014e. Verenig deur die riel. Forum article in Die Burger. 7 January. p.9. . 2015. Die kwessie van Kaaps: Afrikaansonderrig op skool benodig 'n meer inklusiewe benadering. Tydskrif vir Geesteswetenskappe, 55(4):523-539. December.

Le Cordeur, Michael, Olivier, Ria, Prinsloo, Dioné and Jacques van der Elst. (editorial committee). 2012. 16 June 1976: 35 years later. Youth conference presented by the Afrikaans Language
Board at the SU Woordfees. 11-12 March 2011. Pretoria: SA Akademie vir Wetenskap en Kuns.

Le Cordeur, Michael and Marlene Le Roux. 2013. Die Klopse van Wellington; 100 jaar se onvertelde stories. Cape Town: Naledi.

Le Cordeur, Michael and Wannie Carstens. 2013. One nation, eleven languages: How the Afrikaans Language Board took up the challenge to create an ubuntu of languages in South Africa. Expert Lecture: GermanAfrican Language Conference at the University of Pretoria. 25 September.

LitNet. 2014. Dirk Rigter se kommentaar op Jan Rap se: Die Stand van Afrikaans II. 14 April.

Marais, Danie. 2013. Middagtee saam met Nathan Trantraal: Kaaps is nie 'n Joke-taal nie. Die Burger BY. 2 August. pp. 2-3.

Mehrotra, Sanjay. (1998): Education for All: Policy Lessons From High-Achieving Countries. UNICEF Staff Working Papers, New York: Unicef.

Odendaal, Gerda. 2012. Die herstandaardisering van Afrikaans. Unpublished PhD dissertation. Stellenbosch: Stellenbosch University.

Pakendorf, Gunther. 2011. Grond/ Santekraam. LitNet Akademies review essay: 10 November. http://www.litnet. co.za/Article/litnet-akademies-resensieessay-grondsantekraam. [Accessed: 12/04/2014].

Pakendorff, Gunther. 2012. Kaaps in fokus! Report of the symposium at UWC, 19-20 July. LitNet. 26 July.

Rapport. 2014. Kop en hart: Taal van my hart. News24. 18 April. http://m.news24. com/rapport/Opinie/Blogs/Kop-Hart-Dietaal-van-my-hart-20140418. [Accessed: 18/04/2014].

Prins, Jo-Ann. 2013. Digter se aanval op Small verstom. Die Burger. 6 August.

Petersen, Sydney.V. 1959 (1944). Die enkeling. Cape Town: Maskew Miller.

Ponelis, Frederich. 1994. Standaardafrikaans in oorgang. In: February, V. (red.). 1994. Taal en identiteit: Afrikaans and Nederlands. Presentation in the Pieterskerk, Leiden, 23-24 June 1992. Cape Town: Tafelberg. Rabe, Lizette. 2011. Rykie, 'n lewe met woorde. 
Cape Town: Tafelberg.

Raidt, Edith H. 1991. Afrikaans en sy Europese verlede. ( $3^{\text {rd }}$ edition). Cape Town: Nasou.

Ramphele, Mamphele. 2009. Here, mother tongue clashes with her mother's tongue. Sunday Times. 8 March. p. 11.

Rapport. 2013. Net suurknolle sonder grappe. 13 July. p.10.

Roberge, Paul T. 1990. The ideological profile of Afrikaans historical linguistics. In John Joseph. and Talbot J. Taylor. (eds.). Ideologies of Language. London: Routledge. pp. 131-149.

RSA (Republic of South Africa). 1996. The Constitution of the Republic of South Africa. No. 108 of 1996. Pretoria: Government Printer.

Saal, Eric and Joline Blignaut. 2011. "Moetie rai gammattaal gebrykie”: Die gebruik en waarde van gedrukte advertensies. LitNet Akademies, 8(3): December 2011.

Scholtz, Leopold. 2013. Voldoen Kaaps aan vereistes? Die Burger. 16 August. p.11.

Small, Adam. 1962. Kitaar my kruis. Cape Town: HAUM.

Sonn, Franklin. 2014. Gaan soek die helde: Bruinmense moet weet "ons het trotse geskiedenis”. Beeld Forum. 2 April.

Steyn, Jaap C. 1980. Tuiste in eie taal. Cape Town: Tafelberg.

Titus, Danny. 2012. Kaaps is tog te poenankies. Article about the Kaaps conference at the University of the Western Cape, 19-20 July. Rapport. 27 July. p. 12.
Trantraal, Nathan. 2013. Nathan kap Breyten. Die Burger. 2 October. p. 14.

Van der Merwe, Kirby. 2013. Grense vir Kaaps. Die Burger BY. 16 November. p. 5. Van Heerden, Menan. 2013. Kaaps: negotiating language and identity. LitNet. 10 July 2013.

Van Rensburg, Christo. 2012. So kry ons Afrikaans. Pretoria: Protea Boekhuis.

Van Wyk, Steward. 1997. "Ons is nie halfnaaitjies nie/ons is Kaaps": Die wroeging met identiteit by enkele swart Afrikaanse skrywers. Literator, 18(2) Aug.:85-97.

Vilakazi, Herbert. 2002. African indigenous knowledge and development policy. Indilinga: African Journal of Indigenous Knowledge Systems, 1:2.

Willemse, Hein. 2012. S.V. Petersen se poësie van verwantskap. Department of Afrikaans, University of Pretoria: Pretoria.

Willemse, Hein. 2011. Speech delivered during the $1^{\text {st }}$ annual general meeting of the Kaapse Kunste- en Uitsaai-assosiasie (KKUA) and Radio Kaap se Punt. 16 July 2011.

Prof Michael le Cordeur is head of the Department of Curriculum Studies in the Faculty of Education of Stellenbosch University. 